\title{
Effect of Different Level of Inorganic Fertilizer, FYM, and Neem Cake on Soil Properties and Yield Attributes by Carrot (Daucus carota L.)
}

\author{
Deepak Kumar Singh*, Tarence Thomas and Narendra Swaroop \\ Department of Soil Science and Agricultural Chemistry, Naini Agricultural Institute, Sam \\ Higginbottom University of Agriculture, Technology and Science, \\ Prayagraj-211007 (U.P.), India \\ *Corresponding author
}

\section{A B S T R A C T}

\section{Keywords}

Carrot, Soil, Physico-chemical properties of soil, FYM and Neem cake, etc.

\section{Article Info}

Accepted:

15 August 2020

Available Online:

10 September 2020
An experiment was conducted on "Effect of Different Level of Inorganic Fertilizer, FYM, and Neem Cake on Soil Properties and Yield attributes by Carrot (Daucus carota L.)" during Rabi season 2019-20 at the Research farm Department of Soil Science and Agricultural Chemistry, Naini Agriculture Institute, SHUATS, Prayagraj. The design applied was $3 \times 3$ randomized block design having three factors with three levels of N P K @ 0, 50, and $100 \% \mathrm{ha}^{-1}$, two levels of FYM @ 50 and $100 \% \mathrm{ha}^{-1}$ and two levels of neem cake@ @5 and $100 \% \mathrm{ha}^{-1}$ respectively. The result obtained with treatment $\mathrm{T}_{9}$ $100 \%(\mathrm{NPK})+5 \mathrm{t} \mathrm{ha}^{-1} \mathrm{FYM}+5 \mathrm{t} \mathrm{ha}^{-1} \mathrm{NC}$ that showed the best resulted in a slight increase in soil $\mathrm{pH}$ 6.76, Electrical conductivity $0.19 \mathrm{dS} \mathrm{m}^{-1}$. In post-harvest soil of $\mathrm{N} \mathrm{P} \mathrm{K} \mathrm{fertilizers}$ observations were resulted in significant increase in Organic carbon $0.57 \%$, Particle density $2.50 \mathrm{Mg} \mathrm{m}^{-3}$, Bulk density $1.23 \mathrm{Mg} \mathrm{m}^{-3}$, Pore space $55.46 \%$, water holding capacity \% 56.62 and available $\mathrm{N} 321.35 \mathrm{~kg} \mathrm{ha}^{-1}, \mathrm{P} 29.45 \mathrm{~kg} \mathrm{ha}^{-1}, \mathrm{~K} 265.18 \mathrm{~kg} \mathrm{ha}^{-1}$, significant increase in case of Nitrogen $\left(\mathrm{kg} \mathrm{ha}^{-1}\right)$, Phosphorus $\left(\mathrm{kg} \mathrm{ha}^{-1}\right)$, Potassium $\left(\mathrm{kg} \mathrm{ha}^{-1}\right)$ was found to be significant among other treatments in carrot cultivation and soil quality improvement. It was also revealed that the application of N P K with FYM and neem cake was excellent source for fertilization than fertilizers.

\section{Introduction}

Carrot (Daucus carota L.) from Family Apiaceae having chromosome no- $2 \mathrm{n}=18$ is a well-known cool season root crop grown all over India. They are used for human consumption as well as for the forage and particularly for feeding horses (Shweta et al., 2017). Fast- growing cultivars mature within three months (90 days) of sowing the seed, while late maturing cultivars are harvested four months later (120 days).After germination, carrot seedlings show a distinct demarcation between taproot and leaf. Carrot plant is an erect, biennial plant. Leaves have long petiole compound and pinnate (Kochhar, 2011).

Greeks and Romans initially used carrot for medicinal purpose but has now become 
widespread human food and is cultivated all over the world as vegetable (Kochhar, 2011). Carrots grow best in full sun but tolerate some shade (Elzer, 2014) with the optimum temperature of 16 to $21{ }^{\circ} \mathrm{C}$ (61 to $70^{\circ} \mathrm{F}$ ). The ideal soil is deep, loose and well-drained, sandy or loamy, with a $\mathrm{pH}$ of 6.3. They require low levels of nitrogen, moderate phosphate and high potash. India is the second largest producer of vegetables in the world, after China. In India, vegetables are grown in $7.2 \mathrm{~m}$ ha with a production of 113.5 MT with productivity 15.9 tha $^{-1}$.

Carrot cultivars are majorly of two groups, eastern carrots and western carrots (Grubben, 2016). Eastern carrots that survive to the present day are commonly purple or yellow, and often have branched roots. The purple colour common in these carrots comes from anthocyanin pigments (Tiwari et al., 2012). The orange colour in Western carrot results from abundant carotenes in these cultivars. Western carrot cultivars are commonly classified by their root shape (Greene, 2012).

Carrot is an important vegetable root crops and is ranked third among the succulent vegetables in the world production (Yamaguchi, 1983). It is mainly a temperate crop grown during spring through autumn in temperate countries and during winter in tropical and subtropical countries of the world (Bose and Som, 1990). Carrot grows successfully in Bangladesh during rabi season when temperature ranges from 11.17 to 28.9 0C (Alim, 1974) and mid-November to early December is the best time for its cultivation to get satisfactory yield (Rashid, 1993). In the year 2009-2010, the area under carrot cultivation was 1215 ha and total production of 14000 metric tons in Bangladesh (BBS, 2010). Rashid (1999) mentioned an average yield of 25 tha-1 of carrot. This production is relatively low compared to other carrot producing countries like Israel, Australia,
Sweden and Switzerland where the yield are reported to be 58.66, 56.37, 50.56 and 57.60 tha $^{-1}$, respectively (FAO, 2004). The popularity of organic carrot is increasing day by day in Bangladesh especially among the urban people because of its high nutritive value and possible diversified use in making different palatable foods. Vermicompost which is produced by earthworms is a rich source of macro and micro nutrients, vitamins, growth hormones, and enzymes (Bhavalkar, 1991). Among the neem oil cakes, neem and castor cakes are quick acting though insoluble in water and they provide slow and steady nourishment and protection from nematodes and improve yield and quality of produce (Gaur et al., 1992). Insects controlled by neem products include migratory locust, army worms, whitefly and even head lice. The pathogen controls include Meloidogyne rootknot nematode, rhizoctonia root-rot fungus and rice stunt virus (Anonymous, 1992; Anjorin et al., 2004). Neem products improve soil structure as well as increases water holding capacity

Nitrogen imparts dark green colour required for an accelerated photosynthetic behaviour of plants. It increases growth and development of all living tissues area improves succulence of leaf vegetables. A deficiency of nitrogen cause poor plant yield symptoms appears first in older parts of the plant. The whole plant will start yellowing (chlorosis). If the growth is poor, plant spindly and prone to wilting. Nitrogen imparts dark green colour required for an accelerated of all living tissues and improves succulence of leafy vegetables. It increases utilisation of phosphorus and potash to an appreciable extend. Nitrogen is the key to successful organic matter management. To predict total amount of $\mathrm{N}$ needed by a crop, estimates of crop demand, potential indigenous nutrient supply and recovery from applied inorganic and organic sources should be studied. Organic manure was reported to 
increase water holding capacity of the soil making the soil to be loose and friable thereby providing favourable growth condition for carrots (Mehedi et al., 2012). Also, a mixture of inorganic and organic fertilizers has the ability to produce thick carrot root tubers. Early vegetative growth was greatly enhanced by higher doses of Nitrogen fertilizer (Hailu et al., 2008).

\section{Materials and Methods}

The experiment entitled "Effect of different level of inorganic fertilizer, FYM and Neem cake on soil properties and yield attributes by Carrot (Doucuscarota L.)" was conducted during Rabi season of the year 2019-2020 on Department of Soil Science and Agricultural Chemistry, Sam Higginbottom University of Agriculture, Technology, Prayagraj. The area is situated on the south of Prayagraj on the right bank of the river Yamuna at Rewa Road at a distance of about $6 \mathrm{Km}$ from Allahabad city. It is positioned at $25.7^{0} \mathrm{~N}$ latitude and $81.5^{\circ} \mathrm{E}$ latitude and about $90 \mathrm{~m}$ from above sea level.

Prayagraj has subtropical climate, which prevails in the South East part of U.P., with the both extremes of temperature i.e. the winters and the summers. In fairly cold winters (during Oct-Feb), the temperature falls to $4-5^{0} \mathrm{C}$. During summer (March-June) the temperature rises up to $45^{\circ} \mathrm{C}$, sometimes $47-48^{0} \mathrm{C}$ with low relative humidity $(20 \%)$ and dust laden winds. During monsoon (JuneSept) $85 \%$ of average rainfall of $1100 \mathrm{~mm}$ with fall in temperature $40-45^{\circ} \mathrm{C}$ on rainy days. The meteorological data (Dec-2010 to April-2011) with respective to total rainfall, maximum and minimum temperature, relative humidity is presented.

Fertilizers were applied according to recommended doses for carrot, i.e. $\mathrm{N}_{2}: \mathrm{P}_{2} \mathrm{O}_{5}$ : $\mathrm{K}_{2} \mathrm{O} @$ 120: 60: $60 \mathrm{~kg} \mathrm{ha}^{-1}$, FYM @ $5 \mathrm{t} \mathrm{ha}^{-1}$ and Neem cake@ $5 \mathrm{t} \mathrm{ha}^{-1}$. Nitrogen $\left(\mathrm{N}_{2}\right)$ was applied in three equal splits. One third dose of nitrogen, total phosphorus and potash were applied as basal dressing before planting. Remaining dose of $\mathrm{N}_{2}$ was applied in two splits each at 30 DAS and 60 DAS as top dressing.

The experiment was laid out in Randomized Block Design (Fisher, 1925).comprising of 9 treatments each replicated three times. Treatments were randomly arranged in each replication, divided into nine plots (Table 1).

\section{Results and Discussion}

\section{Bulk Density $\left(\mathrm{Mg} \mathrm{m}^{-3}\right)$}

The mean value of bulk density $\left(\mathrm{Mg} \mathrm{m}^{-3}\right)$ of soil was found significant of different levels of Inorganic fertilizer, FYM and Neem cake. The result of the data depicted that the maximum bulk density $\left(\mathrm{Mg} \mathrm{m}^{-3}\right)$ of soil at crop harvest of carrot was found in $T_{1}$ (Control) was 1.46 followed by $\mathrm{T}_{3} 00 \%$ $(\mathrm{NPK})+5 \mathrm{tha}^{-1} \mathrm{FYM}+5 \mathrm{tha}^{-1} \mathrm{NC}, \mathrm{T}_{2} 00 \%$ $(\mathrm{NPK})+2.5 \mathrm{tha}^{-1} \mathrm{FYM}+2.5 \mathrm{tha}^{-1} \mathrm{NC}$, and minimum values of the bulk density $\left(\mathrm{Mg} \mathrm{m}^{-3}\right)$ result was found in $\mathrm{T}_{9} 100 \%(\mathrm{NPK})+5 \mathrm{tha}^{-1}$ $\mathrm{FYM}+5 \mathrm{tha}^{-1} \mathrm{NC}$ was (1.23) (Fig. 1 and 2)

\section{Particle density $\left(\mathrm{Mg} \mathrm{m}^{-3}\right)$}

The mean value of particle density $\left(\mathrm{Mg} \mathrm{m}^{-3}\right)$ of soil was found significant of different levels of Inorganic fertilizer, FYM and Neem cake. The result of the data depicted that the maximum particle density $\left(\mathrm{Mg} \mathrm{m}^{-3}\right)$ of soil at crop harvest of carrot was found in $T_{1}$ (Control) was 2.67 followed by $\mathrm{T}_{2} 00 \%$ $(\mathrm{NPK})+2.5 \mathrm{tha}^{-1} \mathrm{FYM}+2.5 \mathrm{t} \mathrm{ha}^{-1} \mathrm{NC}, \mathrm{T}_{6} 50 \%$ $(\mathrm{NPK})+5 \mathrm{t} \mathrm{ha}{ }^{-1} \mathrm{FYM}+5 \mathrm{t} \mathrm{ha}^{-1} \mathrm{NC}$, and minimum values of the particle density $(\mathrm{Mg}$ $\mathrm{m}^{-3}$ ) result was found in $\mathrm{T}_{9} 100 \%(\mathrm{NPK})+5 \mathrm{t}$ $\mathrm{ha}^{-1} \mathrm{FYM}+5 \mathrm{t} \mathrm{ha}^{-1} \mathrm{NC}$ was (1.50) (Table 2). 
Table.1 Treatment details

\begin{tabular}{|c|c|}
\hline Treatments No. & Treatments Symbols \\
\hline $\mathbf{T}_{1}$ & Control \\
\hline $\mathbf{T}_{2}$ & $00 \%(\mathrm{NPK})+2.5 \mathrm{tha}^{-1} \mathrm{FYM}+2.5 \mathrm{tha}^{-1} \mathrm{NC}$ \\
\hline $\mathbf{T}_{3}$ & $00 \%(\mathrm{NPK})+5 \mathrm{t} \mathrm{ha}^{-1} \mathrm{FYM}+5 \mathrm{t} \mathrm{ha} \mathrm{a}^{-1} \mathrm{NC}$ \\
\hline $\mathbf{T}_{4}$ & $50 \%(\mathrm{NPK})+00 \mathrm{tha}{ }^{-1} \mathrm{FYM}+00 \mathrm{tha}^{-1} \mathrm{NC}$ \\
\hline $\mathbf{T}_{5}$ & $50 \%(\mathrm{NPK})+2.5 \mathrm{tha}^{-1} \mathrm{FYM}+2.5 \mathrm{tha}^{-1} \mathrm{NC}$ \\
\hline $\mathbf{T}_{6}$ & $50 \%(\mathrm{NPK})+5 \mathrm{tha}^{-1} \mathrm{FYM}+5 \mathrm{tha}^{-1} \mathrm{NC}$ \\
\hline $\mathbf{T}_{7}$ & $100 \%(\mathrm{NPK})+00 \mathrm{tha}^{-1} \mathrm{FYM}+00 \mathrm{t} \mathrm{ha} \mathrm{C}^{-1} \mathrm{NC}$ \\
\hline $\mathbf{T}_{8}$ & $100(\mathrm{NPK})+2.5 \mathrm{tha}^{-1} \mathrm{FYM}+2.5 \mathrm{tha}^{-1} \mathrm{NC}$ \\
\hline $\mathbf{T}_{9}$ & $100 \%(\mathrm{NPK})+5 \mathrm{tha}^{-1} \mathrm{FYM}+5 \mathrm{t} \mathrm{ha}^{-1} \mathrm{NC}$ \\
\hline
\end{tabular}

Table.2 Physical analysis of pre harvesting soil

\begin{tabular}{|c|c|c|}
\hline Particulars & Method employed & Results \\
\hline Bulk density $\left(\mathrm{Mg} \mathrm{m}^{-3}\right)$ & Muthuvalet al., 1992 & 1.23 \\
\hline Particle density $\left(\mathrm{Mg} \mathrm{m}^{-3}\right)$ & Muthuvalet al., 1992 & 2.32 \\
\hline Pore Space (\%) & Muthuvalet al., 1992 & 46.98 \\
\hline Water holding capacity (\%) & Muthuvalet al., 1992 & 43.50 \\
\hline
\end{tabular}

Table.3 Chemical analysis of soil

\begin{tabular}{|l|l|l|}
\hline Particulars & Method employed & Results \\
\hline Soil pH (1:2) & Glass electrode, pH meter (Jackson, 1958) & 7.18 \\
\hline Soil EC $\left(\mathbf{d S ~ m} \mathbf{~}^{-\mathbf{1}}\right)$ & EC meter (Digital Conductivity Meter) (Wilcox, 1950) & 0.32 \\
\hline Organic Carbon $\mathbf{( \% )}$ & (Walkley and Black method 1947) & 0.60 \\
\hline Available Nitrogen $\left(\mathbf{k g ~ h a} \mathbf{~}^{-\mathbf{1}}\right)$ & $\begin{array}{l}\text { Alkaline potassium permanganate method } \\
\text { (Subbaih and Asija (1956) }\end{array}$ & 245.26 \\
\hline Available Phosphorus $\left(\mathbf{k g ~ h a}^{-\mathbf{1}}\right)$ & Colorimetric method (Olsen et al., 1954) & 22.05 \\
\hline Available Potassium $\left(\mathbf{k g ~ h a}^{\mathbf{- 1}}\right)$ & Flame photometric method (Toth and Prince, 1949) & 140.62 \\
\hline
\end{tabular}

Table.4 Effect of different level of inorganic fertilizer, FYM, and Neem Cake on physical properties after crop of soil by carrot (Daucus carota L.)

\begin{tabular}{|c|c|c|c|c|}
\hline Treatments No. & $\begin{array}{l}\text { Bulk density } \\
\quad\left(\mathrm{Mg} \mathrm{m}^{-3}\right)\end{array}$ & $\begin{array}{l}\text { Particle density } \\
\left(\mathrm{Mg} \mathrm{m}^{-3}\right)\end{array}$ & $\begin{array}{c}\text { Pore Space } \\
(\%)\end{array}$ & $\begin{array}{l}\text { Water holding capacity } \\
(\%)\end{array}$ \\
\hline$T_{1}$ & 1.46 & 2.67 & 46.13 & 52.18 \\
\hline $\mathbf{T}_{2}$ & 1.36 & 2.61 & 48.18 & 53.31 \\
\hline$T_{3}$ & 1.37 & 2.57 & 49.28 & 54.24 \\
\hline $\mathbf{T}_{4}$ & 1.36 & 2.58 & 50.48 & 55.42 \\
\hline $\mathbf{T}_{5}$ & 1.24 & 2.57 & 50.68 & 55.49 \\
\hline$T_{6}$ & 1.29 & 2.61 & 51.15 & 56.20 \\
\hline $\mathbf{T}_{7}$ & 1.32 & 2.54 & 52.22 & 56.52 \\
\hline $\mathbf{T}_{8}$ & 1.27 & 2.51 & 54.15 & 56.48 \\
\hline $\mathbf{T}_{9}$ & 1.23 & 2.50 & 55.46 & 56.62 \\
\hline F-Test & $\mathrm{S}$ & $\mathrm{S}$ & $\mathrm{S}$ & $S$ \\
\hline C.D. at $0.5 \%$ & 0.081 & 0.102 & 0.340 & 0.340 \\
\hline S.Ed. ( \pm$)$ & 0.038 & 0.048 & 0.160 & 0.160 \\
\hline
\end{tabular}


Table.5 Effect of different level of inorganic fertilizer, FYM, and neem cake on physical properties after crop of soil by carrot (Daucus carota L.)

\begin{tabular}{|c|c|c|c|c|c|c|}
\hline $\begin{array}{l}\text { Treatments } \\
\text { No. }\end{array}$ & pH & EC & $\begin{array}{c}\text { Organic } \\
\text { carbon }(\%)\end{array}$ & $\begin{array}{c}\text { Available nitrogen } \\
\left(\mathrm{kg} \mathrm{ha}^{-1}\right)\end{array}$ & $\begin{array}{c}\text { Available phosphorus } \\
\left(\mathrm{kg} \mathrm{ha}^{-1}\right)\end{array}$ & $\begin{array}{c}\text { Available } \\
\text { potassium }\left(\mathrm{kg} \mathrm{ha}^{-1}\right)\end{array}$ \\
\hline$T_{1}$ & 7.53 & 0.28 & 0.45 & 203.51 & 20.92 & 193.49 \\
\hline $\mathbf{T}_{2}$ & 7.40 & 0.26 & 0.46 & 264.26 & 21.65 & 231.97 \\
\hline $\mathbf{T}_{3}$ & 7.16 & 0.25 & 0.46 & 248.88 & 22.91 & 257.41 \\
\hline $\mathbf{T}_{4}$ & 7.25 & 0.24 & 0.48 & 247.98 & 23.96 & 218.52 \\
\hline $\mathbf{T}_{5}$ & 7.20 & 0.23 & 0.50 & 268.87 & 24.71 & 229.64 \\
\hline$T_{6}$ & 7.25 & 0.23 & 0.51 & 308.87 & 24.31 & 232.22 \\
\hline $\mathbf{T}_{7}$ & 7.05 & 0.22 & 0.53 & 315.62 & 25.44 & 244.19 \\
\hline $\mathbf{T}_{8}$ & 6.82 & 0.22 & 0.55 & 318.21 & 27.15 & 247.22 \\
\hline$T_{9}$ & 6.76 & 0.19 & 0.57 & 321.35 & 29.45 & 265.18 \\
\hline F-Test & $\mathrm{S}$ & $\mathrm{S}$ & $\mathrm{S}$ & $\mathrm{S}$ & $\mathrm{S}$ & $\mathrm{S}$ \\
\hline C.D. at $0.5 \%$ & 0.212 & 0.113 & 0.03 & 9.392 & 1.42 & 4.065 \\
\hline S.Ed. $( \pm)$ & 0.100 & 0.053 & 0.01 & 4.430 & 0.66 & 1.917 \\
\hline
\end{tabular}

Fig.1 Effect of different level of inorganic fertilizer, FYM, and neem cake on physical properties after crop of soil by carrot (Daucus carota $\mathrm{L}$.)

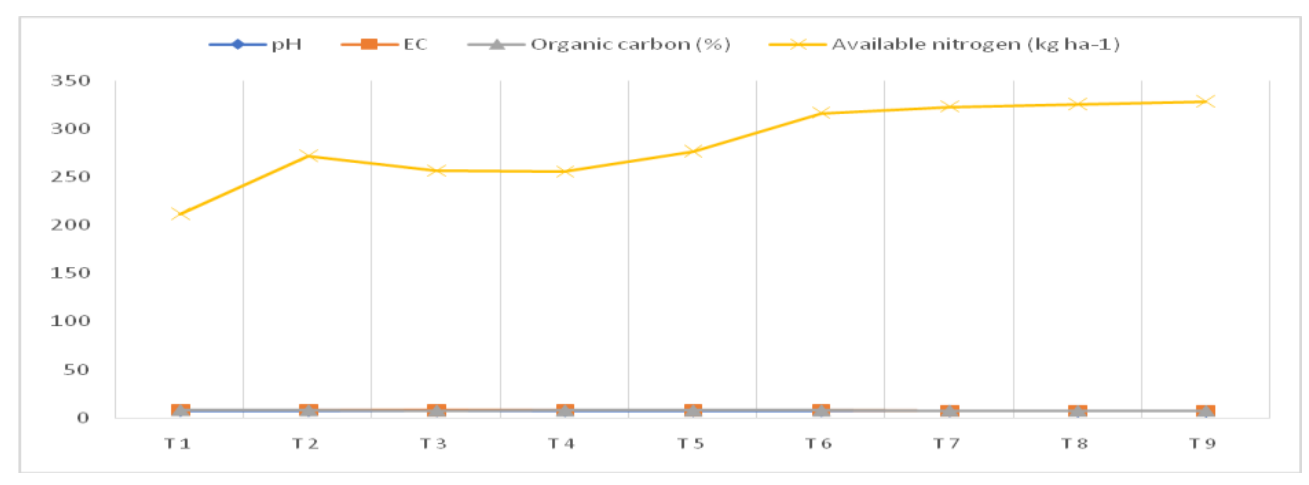

Fig.2 Effect of different level of inorganic fertilizer, FYM, and neem cake on physical properties after crop of soil by carrot (Daucus carota L.)

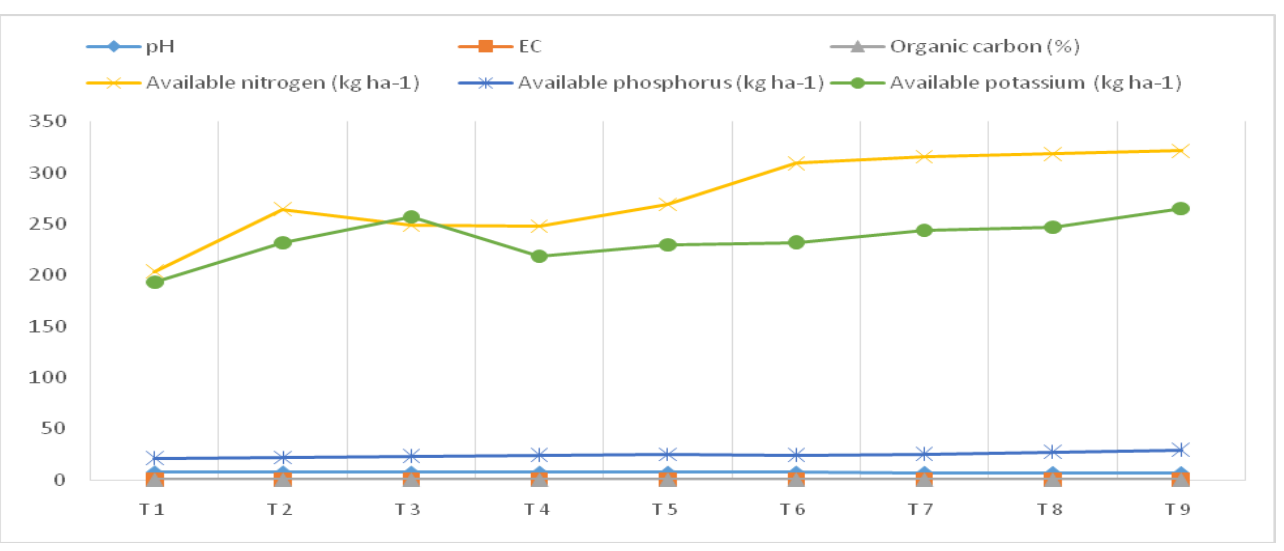




\section{Pore space (\%)}

The mean value of pore space $(\%)$ of soil was found significant of different levels of Inorganic fertilizer, FYM and Neem cake. The result of the data depicted that the maximum pore space $(\%)$ of soil at crop harvest of carrot was found in $\mathrm{T}_{9} 100 \%$ (NPK) $+5 \mathrm{t} \mathrm{ha}^{-1} \mathrm{FYM}+5 \mathrm{t} \mathrm{ha}{ }^{-1} \mathrm{NC}$ was 55.46 followed by $\mathrm{T}_{8} 100(\mathrm{NPK})+2.5 \mathrm{tha}^{-1} \mathrm{FYM}+$ $2.5 \mathrm{t} \mathrm{ha}^{-1} \mathrm{NC}, \mathrm{T}_{7} 100 \%(\mathrm{NPK})+00 \mathrm{tha}^{-1} \mathrm{FYM}$ $+00 \mathrm{tha}^{-1} \mathrm{NC}$ and $\mathrm{T}_{6} 50 \%(\mathrm{NPK})+5 \mathrm{tha}^{-1}$ $\mathrm{FYM}+5 \mathrm{tha}^{-1} \mathrm{NC}$ and minimum values of the pore space $(\%)$ result was found in $\mathrm{T}_{1}$ (Control) was (46.13).

\section{Water holding capacity (\%)}

The mean value of water holding capacity (\%) of soil was found significant of different levels of Inorganic fertilizer, FYM and Neem cake. The result of the data depicted that the maximum water holding capacity $(\%)$ of soil at crop harvest of carrot was found in $\mathrm{T}_{9} 100 \%$ $(\mathrm{NPK})+5 \mathrm{tha}^{-1} \mathrm{FYM}+5 \mathrm{tha} \mathrm{hC}^{-1} \mathrm{NC}$ was 56.62 followed by $\mathrm{T}_{8} 100(\mathrm{NPK})+2.5 \mathrm{t} \mathrm{ha}^{-1} \mathrm{FYM}+$ $2.5 \mathrm{tha}^{-1} \mathrm{NC}, \mathrm{T}_{6} 50 \%(\mathrm{NPK})+5 \mathrm{tha}^{-1} \mathrm{FYM}+$ $5 \mathrm{t} \mathrm{ha}^{-1} \mathrm{NC}$ and $\mathrm{T}_{7} 100 \%(\mathrm{NPK})+00 \mathrm{ha}^{-1}$ $\mathrm{FYM}+00 \mathrm{tha}^{-1} \mathrm{NC}$ and minimum values of the water holding capacity (\%) result was found in $\mathrm{T}_{1}$ (Control) was (52.18).

\section{Soil pH}

The mean value of $\mathrm{pH}$ of soil was found significant of different levels of Inorganic fertilizer, FYM and Neem cake. The result of the data depicted that the maximum $\mathrm{pH}$ of soil at crop harvest of carrot was found in $\mathrm{T}_{1}$ (Control) was 7.53 followed by $\mathrm{T}_{2}: 00 \%$ $(\mathrm{NPK})+2.5 \mathrm{tha} \mathrm{ha}^{-1} \mathrm{FYM}+2.5 \mathrm{tha}^{-1} \mathrm{NC}$, $\mathrm{T}_{4}: 50 \%(\mathrm{NPK})+00 \mathrm{tha}^{-1} \mathrm{FYM}+00 \mathrm{tha}^{-1} \mathrm{NC}$, and $\mathrm{T}_{5}: 50 \%(\mathrm{NPK})+2.5 \mathrm{t} \mathrm{ha}^{-1} \mathrm{FYM}+2.5 \mathrm{t}$ $\mathrm{ha}^{-1} \mathrm{NC}$ and minimum values of the $\mathrm{pH}$ result was found in $\mathrm{T}_{9} 100 \%(\mathrm{NPK})+5 \mathrm{t} \mathrm{ha}$ FYM+5t ha ${ }^{-1} \mathrm{NC}$ was (6.76). May be due to increase in levels of inorganic fertilizer and FYM fertilizer, similar observation was found by (Everaarts and Booi, 2000) (Table 3).

\section{Soil EC (dS m $\left.{ }^{-1}\right)$}

The mean value of EC of soil was found significant of different levels of Inorganic fertilizer, FYM and Neem cake. The result of the data depicted that the maximum EC $(\mathrm{dS}$ $\mathrm{m}^{-1}$ )of soil at crop harvest of carrot was found in $\mathrm{T}_{1}$ (Control) was 0.28 followed by $\mathrm{T}_{2} 00 \%$ $(\mathrm{NPK})+2.5 \mathrm{t} \mathrm{ha}^{-1} \mathrm{FYM}+2.5 \mathrm{tha}^{-1} \mathrm{NC}, \mathrm{T}_{3} 00 \%$ $(\mathrm{NPK})+5 \mathrm{tha} \mathrm{h}^{-1} \mathrm{FYM}+5 \mathrm{tha}{ }^{-1} \mathrm{NC}$ and $\mathrm{T}_{4}$ $50 \%(\mathrm{NPK})+00 \mathrm{tha}^{-1} \mathrm{FYM}+00 \mathrm{t} \mathrm{ha}^{-1} \mathrm{NC}$ and minimum values of the EC result was found in $\mathrm{T}_{9} 100 \%(\mathrm{NPK})+5 \mathrm{t} \mathrm{ha}^{-1} \mathrm{FYM}+5 \mathrm{t}$ $\mathrm{ha}^{-1} \mathrm{NC}$ was (0.19).The treatments as regarded both for $\mathrm{pH}$ and $\mathrm{EC}$ of the soil were found significant statistically for both the years of experimentation results were same reported by (Tadesse et al., 2013) and (Hemalata et al., 2013).

\section{Organic carbon $(\%)$}

The mean value of $(\%)$ Organic carbon of soil was found significant of different levels of Inorganic fertilizer, FYM and Neem cake. The result of the data depicted that the maximum Organic carbon(\%) of soil at crop harvest of carrot was found in $\mathrm{T}_{9} 100 \%$ (NPK) $+5 \mathrm{t} \mathrm{ha}{ }^{-1} \mathrm{FYM}+5 \mathrm{t} \mathrm{ha}{ }^{-1} \mathrm{NC}$ was (0.57) followed by $\mathrm{T}_{5} 50 \%(\mathrm{NPK})+2.5 \mathrm{t} \mathrm{ha}^{-1} \mathrm{FYM}$ $+2.5 \mathrm{t} \mathrm{ha}^{-1} \mathrm{NC}, \mathrm{T}_{7} 100 \%(\mathrm{NPK})+00 \mathrm{tha}^{-1}$ $\mathrm{FYM}+00 \mathrm{tha}^{-1} \mathrm{NC}$ and $\mathrm{T}_{8} 100(\mathrm{NPK})+2.5 \mathrm{t}$ $\mathrm{ha}^{-1} \mathrm{FYM}+2.5 \mathrm{t} \mathrm{ha}^{-1} \mathrm{NC}$ and minimum values of the Organic carbon(\%)result was found in $_{1}$ Control was (0.45) (Table 4 and 5).

\section{Available nitrogen $\left(\mathrm{kg} \mathrm{ha}^{-1}\right)$}

The mean value of Available nitrogen $\left(\mathrm{kg} \mathrm{ha} \mathrm{h}^{-1}\right.$ ) of soil was found significant of different levels of Inorganic fertilizer, FYM and Neem cake. The result of the data 
depicted that the maximum Available nitrogen $\left(\mathrm{kg} \mathrm{ha}^{-1}\right)$ of soil at crop harvest of carrot was found in $\mathrm{T}_{9} 100 \%(\mathrm{NPK})+5 \mathrm{t} \mathrm{ha}^{-1}$ $\mathrm{FYM}+5 \mathrm{t} \mathrm{ha}^{-1} \mathrm{NC}$ was $\left(321.35 \mathrm{~kg} \mathrm{ha}^{-1}\right)$ followed by $\mathrm{T}_{8} 100(\mathrm{NPK})+2.5 \mathrm{tha}^{-1} \mathrm{FYM}+$ $2.5 \mathrm{t} \mathrm{ha}^{-1} \mathrm{NC}, \mathrm{T}_{7} 100 \%(\mathrm{NPK})+00 \mathrm{tha}^{-1} \mathrm{FYM}$ $+00 \mathrm{tha}^{-1} \mathrm{NC}$, and $\mathrm{T}_{3} 00 \%(\mathrm{NPK})+5 \mathrm{tha}^{-1}$ $\mathrm{FYM}+5 \mathrm{tha}^{-1} \mathrm{NC}$ and minimum values of the Available nitrogen $\left(\mathrm{kg} \mathrm{ha}^{-1}\right)$ result was found in $_{1}$ Control was $\left(203.51 \mathrm{~kg} \mathrm{ha}^{-1}\right)$. (Tadesse et al., 2013) and (Hemalata et al., 2013) also reported the similar findings.

\section{Available Phosphorus (kg ha $\left.{ }^{-1}\right)$}

The mean value of Available potassium ( $\mathrm{kg}$ $\mathrm{ha}^{-1}$ ) of soil was found significant of different levels of Inorganic fertilizer, FYM and Neem cake. The result of the data depicted that the maximum Available potassium $\left(\mathrm{kg} \mathrm{ha}^{-1}\right)$ of soil at crop harvest of carrot was found in ${ }_{9} 100 \%(\mathrm{NPK})+5 \mathrm{tha}^{-1} \mathrm{FYM}+5 \mathrm{tha}^{-1} \mathrm{NC}$ was $\left(29.45 \mathrm{~kg} \mathrm{ha}^{-1}\right)$ followed by $\mathrm{T}_{8} 100$ (NPK) $+2.5 \mathrm{tha}^{-1} \mathrm{FYM}+2.5 \mathrm{tha}^{-1} \mathrm{NC}, \mathrm{T}_{7} 100 \%$ $(\mathrm{NPK})+00 \mathrm{tha}^{-1} \mathrm{FYM}+00 \mathrm{tha}^{-1} \mathrm{NC}$ and $\mathrm{T}_{6}$ $50 \%(\mathrm{NPK})+5 \mathrm{t} \mathrm{ha}^{-1} \mathrm{FYM}+5 \mathrm{t} \mathrm{ha}^{-1} \mathrm{NC}$, and minimum values of the Available potassium $\left(\mathrm{kg} \mathrm{ha}^{-1}\right)$ result was found in $\mathrm{T}_{1}$ Control was (20.96 kg ha ${ }^{-1}$ ). Corroborative findings also were reported by (Tadesse et al., 2013) and (Hemalata et al., 2013).

\section{Available Potassium (kg ha $\left.{ }^{-1}\right)$}

The mean value of Available potassium $(\mathrm{kg}$ $\mathrm{ha}^{-1}$ ) of soil was found significant of different levels of Inorganic fertilizer, FYM and Neem cake. The result of the data depicted that the maximum Available potassium $\left(\mathrm{kg} \mathrm{ha}^{-1}\right)$ of soil at crop harvest of carrot was found in $\mathrm{T}_{9}$ $100 \%(\mathrm{NPK})+5 \mathrm{tha}^{-1} \mathrm{FYM}+5 \mathrm{t} \mathrm{ha}^{-1} \mathrm{NC}$ was $\left(193.49 \mathrm{~kg} \mathrm{ha}^{-1}\right)$ followed byT $100(\mathrm{NPK})+$ $2.5 \mathrm{t} \mathrm{ha}^{-1} \mathrm{FYM}+2.5 \mathrm{t} \mathrm{ha}^{-1} \mathrm{NC}, \mathrm{T}_{7} 100 \%$ (NPK) $+00 \mathrm{tha}^{-1} \mathrm{FYM}+00 \mathrm{tha}^{-1} \mathrm{NC}$, and $\mathrm{T}_{3} 00 \%$ $(\mathrm{NPK})+5 \mathrm{t} \mathrm{ha} \mathrm{h}^{-1} \mathrm{FYM}+5 \mathrm{t} \mathrm{ha} \mathrm{hC}^{-1} \mathrm{NC}$ and minimum values of the Available potassium $\left(\mathrm{kg} \mathrm{ha}^{-1}\right)$ result was found in $\mathrm{T}_{1}$ Control was $\left(265.18 \mathrm{~kg} \mathrm{ha}^{-1}\right)$. (Singh 2007) and (Hemalata et al., 2013) have been reported the similar results.

In conclusion the treatment combination $\mathrm{T}_{9}$ $100 \%(\mathrm{NPK})+5 \mathrm{t} \mathrm{ha}{ }^{-1} \mathrm{FYM}+5 \mathrm{ha}^{-1}$ was appropriate for Carrot on Prayagraj. Physicalchemical properties of soil were also improved significantly in same treatment combination of $\mathrm{T}_{9} 100 \%(\mathrm{NPK})+5 \mathrm{tha}^{-1}$ $\mathrm{FYM}+5 \mathrm{tha}^{-1}$.

\section{Acknowledgement}

I am grateful to the Hon' able Vice chancellor SHUATS, department of Soil Science and Agricultural Chemistry, Naini Agriculture Institute, Sam Higginbottom University of Agriculture, Technology and Sciences, Prayagraj, Uttar Pradesh, for taking their keen interest and encouragement to carry out the research work.

\section{References}

Ali, Abu S. M. Y., Solaiman, Abul H. M. and Saha, K. C. (2016) Influence of Organic Nutrient Sources and Neem (Azadirachta) Products on Growth and Yield of Carrot. International Journal of Crop Science and Technology, Volume 2, Issue 1, Page 1925. ISSN: $2458-7540$.

Black, C.A. (1965) Methods of soil analysis vol.2, Am. Soc, Argon. Madison, Wisconsin, U.S.A.

Bouyoucos, G. J. (1927) The hydrometer as a new method for the mechanical analysis of soils. Soil Sci., 23: 393-395.

Elzer-Peters, K. (2014) Midwest Fruit \& Vegetable Gardening: Plant, Growth, and Harvest the Best Edibles - Illinois, Indiana, Iowa, Kansas, Michigan, Minnesota, Missouri, Nebraska, North Dakota, Ohio, South Dakota \& Wisconsin. Cool Springs Press. p. 136.

Everaarts, A.P. and Booi, R. (2007) The effect of nitrogen application on nitrogen 
utilization by white cabbage (Brassica oleracea var. capitata) and on nitrogen in the soil at harvest. 2000; 75(6):705-712.

Fisher, R. A. (1925) Technique of Analysis of Variance. Handbook of Agricultural Statistics B-29- 110.

Greene, Wesley (2012) Vegetable Gardening the Colonial Williamsburg Way: 18thCentury Methods for Today's Organic Gardeners. Rodale. Pp. 81.

Hailu, S., Seyoum, T. and Dechassa, N. (2008) Effect of combined application of organic$\mathrm{P}$ and inorganic-N fertilizers on yield of carrot. African Journal of Biotechnology, 7 (1) 27-34

Hemlatha, S., Radhika, K., Maragatham, S., And Katharine, S. (2013) Influence of Longterm Fertilization on Soil Fertility- A Review. Research and Reviews: J. Agri. and Allied Sci. 2, 30- 36.

Jackson, M.L. (1958) Soil Chemical Analysis, Prentice Hall of India Private Limited, New Delhi.

Kochhar, S. L. (2011) Economic Botany in the Tropics. Fourth Edition, pp245-246. Macmillan

Mehedi. T. A., Siddique. M. A and Sonia, B. S. (2012) Effects of Urea and Cowdung on growth and yield of Carrot. Bangladesh Agricultural Research Institute, Gazipur. p. 94.10 (1): 9- 13.

Munsell, A.H., ed. 12, (1971) A Colour Notation.Baltimore, MD: Munsell Color Company. Pp. 65.

Muthuval P., Udaysoorian, C., Natesan, R. and
Ramaswami, P.P. (1992) Introduction to Soil analysis, Tamil Nadu Agricultural University, Coimbatore-641002.

Olsen, S.R., Watanale, F.S. (1954) A method to determine a phosphorus adsorption measured by colorimetric method soil sci. soc. Am. J. 21, 144-149.

Shweta Soni, Rumi Debbarma, Govind Vishwakarma and Pradeep K. (2017) A study on efficacy of organic and inorganic fertilizers on growth and yield of carrot (Daucus carota L.) var. Pusa Meghali under Dehradun valley condition. International Journal of Chemical Studies; 7(4): 2310-2312.

Subbiah, B.V. and Asija, C.L. (1956) A rapid procedure for the estimation of available nitrogen in soil, Current Sci. 25 259-260.

Tadesse, T., Dechassa, N., Bayu, W., and Gebeyenhu, S. (2013) Effects of Farmyard Manure and Inorganic fertilize Application on Soil Physicochemical Properties and Nutrient Balance in RainFed Lowland Rice Ecosystem. American J. Plant Sci. 4, 309-316.

Walkey, A. and Black, I. A. (1947) Critical examination of rapid method for determining organic carbon in soils, effect of variance in digestion conditions and of inorganic soil constituents. Soil Sci., pp. 632:251.

Wilcox (1950) Electrical conductivity. Am water work Assoc. J., 42; pp 775-776.

\section{How to cite this article:}

Deepak Kumar Singh, Tarence Thomas and Narendra Swaroop. 2020. Effect of Different Level of Inorganic Fertilizer, FYM, and Neem Cake on Soil Properties and Yield Attributes by Carrot (Daucus carota L.). Int.J.Curr.Microbiol.App.Sci. 9(09): 1818-1825. doi: https://doi.org/10.20546/ijcmas.2020.909.228 